\title{
Analysis of Elements and Foods for the Human Body and Avoiding the Unnecessary Diseasesusing Big Data and Artificial Intelligence (Food Advisor)
}

\author{
N.Ambiga, M. C. A, M. Phil, M. B. A \\ Assistant professor, Department of computer science, Sri Akilandeswari women's college, Wandiwash-604408, \\ Tamilnadu, INDIA
}

\begin{abstract}
Human beings are living with the food. This food is the combination of elements to the body. The body contains lot of elements.The levels of these elements in human body may differ from one person to another.if there is a change in the level of these elements in the human body then disease occurs. This paper presents the theoretical aspect of a device which measures the elements in the body at regular intervals and asks the people to take the necessary food daily. This can be The hand held device like a tab and using the samples like blood, urine, saliva, hait it will list all elements in the human body and give the percentag of that.if it decreases it will alert the people to take the the food that contains.for example if iron level decreases it will advise you how much gram iron must be taken for the healthy living.the elements should be measured at proper intervals or regularly. Food Advisor the is the proposed medical instrument that is given theoretically or a a device which can measure the quantity of the element in the human body and advises the people to take the necessary food at regular intervals or daily. When there is a decrease or increase in the elements percentage in the human body occurs then this food advisor will instruct the people to take the appropriate food in a specified quantity.
\end{abstract}

\section{Introduction}

Nearly $99 \%$ of the mass of your human body consists of just 6 chemical elements: oxygen, carbon, hydrogen, nitrogen, calcium, and phosphorus. Another 5 elements make up most of the last percentage point: potassium, sulfur, sodium, chlorine, and magnesium. Although required in very small amounts, trace elements such as iron, iodine, fluoride, copper, zinc, chromium, selenium, manganese and molybdenum are vital for maintaining health. Also referred to as micro minerals, these trace elements are part of enzymes, hormones and cells in the body. Insufficient intake of trace minerals can cause symptoms of nutritional deficiency. However, your needs for these trace elements are easily met by eating a variety of foods from the different food groups.

\section{Detection of Elements}

Elements can be identified and quantity of each and every element must be measured and recorded. the element are found in saliva,urine,blood,hair etc.

\section{Introduction To Elements}

The four main elements that are connected to the human body are oxygen,carbon, hydrogen and nitrogen. $96 \%$ of the human body is made up of these following elements in common.

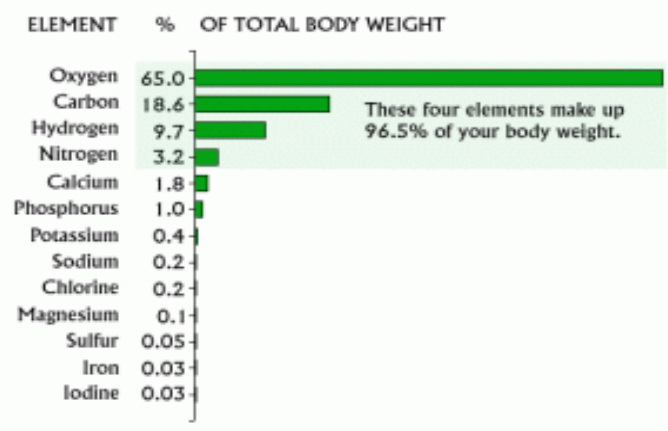

There are 92 naturally occurring elements on Earth, from hydrogen to uranium. They are versatile elements, capable of producing a vast array of chemical compounds. They are among the most abundant elements in the universe. 


\section{History Of Elements}

The first elements appeared minutes after the big bangthrough a process known as nucleosynthesis. The elements produced by the big bang consisted of about $75 \%$ hydrogen and $25 \%$ helium (by mass) with trace amounts of lithium and beryllium. For the next several hundred million years only these four elements existed. Then the first stars appeared. They formed from large clouds of hydrogen and helium, and as they collapsed under their own weight the hydrogen in their cores began to fuse into helium.

The energy produced by this nuclear fusion gives a star the light and heat necessary to counter the force of gravity for a time, but as a star ages, the amount of helium is increased. As helium become more plentiful in the stars core, some of it fuses into carbon. The carbon interacts with the hydrogen to produce nitrogen and oxygen as well as helium.

The first stars are thought to have been very large stars. Toward the end of their lives they produced even heavier elements, such as silicon, neon, and eventually iron. Beyond iron there are no elements a star can fuse to produce energy. After several hundred thousand years these first stars had no further way to produce energy, and in the end they explode in a massive explosion known as a supernova. The gas and dust of these stars were tossed out into the universe. Over time this gas and dust became part of clouds that formed new stars, which also fused hydrogen and helium into heavier elements until they too died in supernova explosions.

Elemental inclusion in organoids is consistent with human brain tissue and involves $\mathrm{P}, \mathrm{S}, \mathrm{K}, \mathrm{Ca}, \mathrm{Fe}$ and $\mathrm{Zn}$.Then about five billion years ago a cloud of gas and dust began to form a new star. Thanks to the lives and deaths of earlier generations of stars this cloud was rich not just in hydrogen and helium, but also in carbon, nitrogen, oxygen, and iron. As the star formed, some of the dust formed a disk around the star, out of which formed planets. The third planet from this star had the good fortune of being not too close to the star and not too far away.

The elements in our body contain the history of the universe. The hydrogen inour body was born among the first elements, about 13.7 billion years ago. The carbon, nitrogen and oxygen in our muscles and mind were created within a star that died more than 5 billion years ago.

The table below gives the amount of each chemical element found in the human body, from most to least redundant. For each element, there is the amount in mass units in an averge (70-kilogram) person, the volume of the element, and the length of the side of a cube that would contain that amount of the pure element. Volumes of solid and liquid elements are based on density at or near room temperature (where available). For the gaseous elements (oxygen, hydrogen, nitrogen, chlorine, and fluorine), used the density of each in the liquid state at the respective boiling point.

Element Mass of element in a 70-kg person volume of purified element Element would Comprise a cube this long on a side:

Element. Weight of a person qtyof element

$\begin{array}{lccc}\text { oxygen } & 43 \mathrm{~kg} & 37 \mathrm{~L} & 33.5 \mathrm{~cm} \\ \text { carbon } & 16 \mathrm{~kg} & 7.08 \mathrm{~L} & 19.2 \mathrm{~cm} \\ \text { hydrogen } & 7 \mathrm{~kg} & 98.6 \mathrm{~L} & 46.2 \mathrm{~cm} \\ \text { nitrogen } & 1.8 \mathrm{~kg} & 2.05 \mathrm{~L} & 12.7 \mathrm{~cm} \\ \text { calcium } & 1.0 \mathrm{~kg} & 645 \mathrm{~mL} & 8.64 \mathrm{~cm} \\ \text { phosphorus } & 780 \mathrm{~g} & 429 \mathrm{~mL} & 7.54 \mathrm{~cm} \\ \text { potassium } & 140 \mathrm{~g} & 162 \mathrm{~mL} & 5.46 \mathrm{~cm} \\ \text { sulphur } & 140 \mathrm{~g} & 67.6 \mathrm{~mL} & 4.07 \mathrm{~cm} \\ \text { sodium } & 100 \mathrm{~g} & 103 \mathrm{~mL} & 4.69 \mathrm{~cm} \\ \text { chlorine } & 95 \mathrm{~g} & 63 \mathrm{~mL} & 3.98 \mathrm{~cm} \\ \text { magnesium } & 19 \mathrm{~g} & 10.9 \mathrm{~mL} & 2.22 \mathrm{~cm} \\ \text { iron } & 4.2 \mathrm{~g} & 0.53 \mathrm{~mL} & 8.1 \mathrm{~mm} \\ \text { fluorine } & 2.6 \mathrm{~g} & 1.72 \mathrm{~mL} & 1.20 \mathrm{~cm} \\ \text { zinc } & 2.3 \mathrm{~g} & 0.32 \mathrm{~mL} & 6.9 \mathrm{~mm} \\ \text { silicon } & 1.0 \mathrm{~g} & 0.43 \mathrm{~mL} & 7.5 \mathrm{~mm} \\ \text { rubidium } & 0.68 \mathrm{~g} & 0.44 \mathrm{~mL} & 7.6 \mathrm{~mm} \\ \text { strontium } & 0.32 \mathrm{~g} & 0.13 \mathrm{~mL} & 5.0 \mathrm{~mm} \\ \text { bromine } & 0.26 \mathrm{~g} & 64.2 \mu \mathrm{L} & 4.0 \mathrm{~mm} \\ \text { lead } & 0.12 \mathrm{~g} & 10.6 \mu \mathrm{L} & 2.2 \mathrm{~mm} \\ \text { copper } & 72 \mathrm{mg} & 8.04 \mu \mathrm{L} & 2.0 \mathrm{~mm} \\ \text { aluminum } & 60 \mathrm{mg} & 22 \mu \mathrm{L} & 2.8 \mathrm{~mm} \\ \text { cadmium } & 50 \mathrm{mg} & 5.78 \mu \mathrm{L} & 1.8 \mathrm{~mm} \\ \text { cerium } & 40 \mathrm{mg} & 4.85 \mu \mathrm{L} & 1.7 \mathrm{~mm} \\ \text { barium } & 22 \mathrm{mg} & 6.12 \mu \mathrm{L} & 1.8 \mathrm{~mm} \\ & & & \end{array}$


iodine $\quad 20 \mathrm{mg} \quad 4.06 \mu \mathrm{L} \quad 1.6 \mathrm{~mm}$

tin $20 \mathrm{mg} 3.48 \mu \mathrm{L} 1.5 \mathrm{~mm}$

titanium $20 \mathrm{mg} 4.41 \mu \mathrm{L} 1.6 \mathrm{~mm}$

boron $18 \mathrm{mg} 7.69 \mu \mathrm{L} 2.0 \mathrm{~mm}$

nickel $15 \mathrm{mg} 1.69 \mu \mathrm{L} 1.2 \mathrm{~mm}$

selenium $15 \mathrm{mg} 3.13 \mu \mathrm{L} 1.5 \mathrm{~mm}$

chromium $14 \mathrm{mg} 1.95 \mu \mathrm{L} 1.3 \mathrm{~mm}$

manganese $12 \mathrm{mg} 1.61 \mu \mathrm{L} 1.2 \mathrm{~mm}$

arsenic $7 \mathrm{mg} 1.21 \mu \mathrm{L} 1.1 \mathrm{~mm}$

lithium $7 \mathrm{mg} 13.1 \mu \mathrm{L} 2.4 \mathrm{~mm}$

cesium $6 \mathrm{mg} 3.2 \mu \mathrm{L} 1.5 \mathrm{~mm}$

mercury $6 \mathrm{mg} 0.44 \mu \mathrm{L} 0.8 \mathrm{~mm}$

germanium $5 \mathrm{mg} 0.94 \mu \mathrm{L} 1.0 \mathrm{~mm}$

molybdenum $5 \mathrm{mg} 0.49 \mu \mathrm{L} 0.8 \mathrm{~mm}$

cobalt $3 \mathrm{mg} 0.34 \mu \mathrm{L} 0.7 \mathrm{~mm}$

antimony $2 \mathrm{mg} 0.30 \mu \mathrm{L} 0.7 \mathrm{~mm}$

silver $2 \mathrm{mg} 0.19 \mu \mathrm{L} 0.6 \mathrm{~mm}$

niobium $1.5 \mathrm{mg} 0.18 \mu \mathrm{L} 0.6 \mathrm{~mm}$

zirconium $1 \mathrm{mg} 0.15 \mu \mathrm{L} 0.54 \mathrm{~mm}$

lanthanium $0.8 \mathrm{mg} 0.13 \mu \mathrm{L} 0.51 \mathrm{~mm}$

gallium $0.7 \mathrm{mg} 0.12 \mu \mathrm{L} 0.49 \mathrm{~mm}$

tellurium $0.7 \mathrm{mg} 0.11 \mu \mathrm{L} 0.48 \mathrm{~mm}$

yttrium $0.6 \mathrm{mg} 0.13 \mu \mathrm{L} 0.51 \mathrm{~mm}$

bismuth $0.5 \mathrm{mg} 51 \mathrm{~nL} 0.37 \mathrm{~mm}$

thallium $0.5 \mathrm{mg} 42 \mathrm{~nL} 0.35 \mathrm{~mm}$

indium $0.4 \mathrm{mg} 55 \mathrm{~nL} 0.38 \mathrm{~mm}$

gold $0.2 \mathrm{mg} 10 \mathrm{~nL} 0.22 \mathrm{~mm}$

scandium $0.2 \mathrm{mg} 67 \mathrm{~nL} 0.41 \mathrm{~mm}$

tantalum $0.2 \mathrm{mg} 12 \mathrm{~nL} 0.23 \mathrm{~mm}$

vanadium $0.11 \mathrm{mg} 18 \mathrm{~nL} 0.26 \mathrm{~mm}$

thorium $0.1 \mathrm{mg} 8.5 \mathrm{~nL} 0.20 \mathrm{~mm}$

uranium $0.1 \mathrm{mg} 5.3 \mathrm{~nL} 0.17 \mathrm{~mm}$

samarium $50 \mu \mathrm{g} 6.7 \mathrm{~nL} 0.19 \mathrm{~mm}$

beryllium $36 \mu \mathrm{g} 20 \mathrm{~nL} 0.27 \mathrm{~mm}$

tungsten $20 \mu \mathrm{g} 1.0 \mathrm{~nL} 0.10 \mathrm{~m}$

The above experimented sample gives the element present and their quantity in the human body.t his samples can be compared with the standards .for example if oxygen level decreases then food advisor will check immedialy and advice to take the oxygen immediately.for example if iron content is low it will advice you to take the food rich in iron content.

Oxygen is the most abundant element in the earth's crust and in the body. The body's 43kilograms of oxygen is found mostly as a component of water, which makes up $70 \%$ of total body weight. Oxygen is also an integral component of all proteins, nucleic acids (DNA and RNA), carbohydrates, and fats.

Rubidium is the most abundant element in the body (0.68 g) that has no known biological role.(silicon, which is slightly more abundant, may or may not have a metabolic function).

Vanadium is the body's least abundant element $(0.11 \mathrm{mg})$ that has a known biologic role,followed by cobalt (3 $\mathrm{mg}$ ), the latter being a constituent of vitamin B12.The last of the body's elements to be discovered was fluorine.

\section{Elements in the Human Body and their effect}

Oxygen $(0)-65 \%$ of body weight

Oxygen is the most abundant element in the human body. It's mainly found bound to hydrogenin the form of water. Water, in turn, makes up about $60 \%$ of the human body and participates incountless metabolic reactions. The element oxygen acts as an electron acceptor and oxidizingagent. It is found in all four of the major classes 
of organic molecules: protein, carbohydrates, lipids, and nucleic acids. Because it is a key element in aerobic cellular respiration, largeamounts of oxygen are found in the lungs and in the bloodstream. Hemoglobin in blood bind theoxygen molecule, $\mathrm{O} 2$, from inhaled air. Oxygen is used by the mitochondria in cells to produce the energy molecule adenosine triphosphate or ATP. While it's essential for human life, too much oxygen can be deadly, as it can lead to oxidative damage to cells and tissues.

\section{Carbon (C) $-\mathbf{1 8 \%}$ of body weight}

Carbon is the second most abundant element in the human body and the element that is considered the basis of organic chemistry. Every single organic molecule in your body contains carbon. The element bonds to itself to form chains and ring structures that serve as the basis for all metabolic reactions in the body. Carbon in carbon dioxide is expelled as a waste product when you breathe.

\section{Hydrogen $(\mathrm{H})-\mathbf{1 0} \%$ of body weight}

Most of the hydrogen in the body is bound with oxygen to form water, H2O. Hydrogen, like carbon, is found in every single organic molecule in the body. Hydrogen also acts as a proton or positive ion in chemical reactions.

\section{Nitrogen $(N)-3 \%$ of body weight}

Because most of air consists of nitrogen, nitrogen gas is found in the lungs, but it is not absorbedinto the body that way. Humans get nitrogen from food. The element is an important component of amino acids, which are used to build peptides and proteins. Nitrogen is also an essential component of the nucleic acids DNA and RNA and all of the other molecules derived from the nitrogenous bases.

\section{Calcium (Ca) $-1.4 \%$ of body weight}

About $99 \%$ of the body's calcium is found in bones and teeth, where the element is used to build strong structural compounds, such as hydroxyapatite. Although most of the calcium is in bones and teeth, this is not the mineral's most important function. Calcium is an important ion, used in muscle contraction and protein regulation. If any critical function has insufficient calcium, the body will actually pull it out of the bones and teeth. This can lead to osteoporosis and other problems, so it's important to get enough dietary calcium.

\section{Phosphorus (P) - 1\% of body weight}

Like calcium, the element and mineral phosphorus is found in the bones and teeth. The element is also found in nucleic acids and energy molecules, such as ATP (adenosine triphosphate).Phosphorus (1\%) is found predominantly in bone but also in the molecule ATP, which provides energy in cells for driving chemical reactions.

Potassium (K) $-\mathbf{0 . 2 5 \%}$

Electrochemistry in the body depends on ions. Of these, the cation potassium is among the most important. Potassium is used in nerve conduction and regulating the heart beat. All cells in the body require potassium in order to function.

Sulfur (S) $-0.25 \%$

Sulfur is found in several important amino acids, which are used to build proteins in the body .Sulfur is found in biotin, methionine, thiamine, and cysteine.

Sodium (Na) - $0.15 \%$

Sodium, like potassium, is an essential cation. This element is important for nerve transmission and muscle function.

Chlorine (Cl) - $\mathbf{0 . 1 5 \%}$

Chlorine is an important anion. One of its functions involves the transport of the enzyme ATPase, which is used to supply energy for biochemical reactions. Chlorine is used to make hydrochloric acid, which is found in the stomach and digests food.

\section{Magnesium (Mg) - $0.005 \%$}

Magnesium binds to ATP and nucleotides. Its cation is an important cofactor for enzymatic reactions.magnesium is used to build healthy teeth and bones. Magnesium $(0.05 \%)$ plays an important role in the structure of the skeleton and muscles. It also is necessary in more than 300 essential metabolic reactions. 
Potassium $(0.25 \%)$ is an important electrolyte (meaning it carries a charge in solution). It helps regulate the heartbeat and is vital for electrical signaling in nerves.

$\operatorname{Sulfur}(0.25 \%)$ is found in two amino acids that are important for giving proteins their shape.

Sodium $(0.15 \%)$ is another electrolyte that is vital for electrical signaling in nerves. It also regulates the amount of water in the body.

Chlorine $(0.15 \%)$ is usually found in the body as a negative ion, called chloride. This electrolyte is important for maintaining a normal balance of fluids.

Iron $(0.006 \%)$ is a key element in the metabolism of almost all living organisms. It is also found in haemoglobin, which is the oxygen carrier in red blood cells. Half of women don't get enough iron in their diet. a component of hemoglobin in blood, one of the most important functions of iron is to transport oxygen from the lungs to different parts of the body. In myoglobin, iron enables storage of oxygen in muscle cells. Iron is also part of many enzymes and is essential for growth, healing, immune function and synthesis of DNA. For adequate intakes of this essential nutrient, include foods such as beef, poultry, fish, soybean flour, spinach, beans and fortified cereals in your diet.

Calcium $(1.5 \%)$ is the most common mineral in the human body - nearly all of it found in bones and teeth. Ironically, calcium's most important role is in bodily functions, such as muscle contraction and protein regulation. In fact, the body will actually pull calcium from bones (causing problems like osteoporosis) if there's not enough of the element in a person's diet.

Fluorine $(0.0037 \%)$ is found in teeth and bones. Outside of preventing tooth decay, it does not appear to have any importance to bodily health. Well recognized for its role in forming bones and teeth, fluoride is present in the body as calcium fluoride. Fluoride hardens tooth enamel, reduces incidence of tooth decay and may prevent bone loss. While your main source of fluoride is fluoridated water, fluorine is also present in saltwater fish, tea and coffee.

Zinc $(0.0032 \%)$ is an essential trace element for all forms of life. Several proteins contain structures called "zinc fingers" help to regulate genes. Zinc deficiency has been known to lead to dwarfism in developing countries. In addition to its role in formation of enzymes, zinc improves immune function, helps clot blood, maintains sense of taste and smell, keeps skin healthy and enables normal growth and development. You can obtain sufficient amounts of zinc by regularly eating eggs, seafood, red meats, fortified cereals and whole grain

Copper $(0.0001 \%)$ is important as an electron donor in various biological reactions. Without enough copper, iron won't work properly in the body. Copper prevents damage to cells due to its antioxidant action, and as a component of many enzymes it helps in production of energy from carbohydrates, protein and fat. Copper is also essential for formation of bone, connective tissues and red blood cells. It is present in many foods including organ meats, shellfish, chocolate, beans and whole-grain cereal Chromium and Selenium

Chromium is an important trace mineral that is necessary for normal functioning of insulin, a hormone that maintains blood sugar levels. It is also essential for metabolism of carbohydrates, proteins and fats. Some important sources of chromium include liver, processed meats, brewer's yeast, whole grains, cheese and nuts. Selenium, along with vitamin E works as an antioxidant that prevents damage of cells, may prevent some cancers and is essential for the normal functioning of the thyroid gland. Meat, seafood, nuts and cereals are good sources of selenium.

\section{Manganese and Molybdenum}

Manganese not only helps in the formation of enzymes, but is also necessary for their activation. It works as an antioxidant, helps develop bones and heals wounds by increasing collagen production. Good sources of manganese include pineapple, nuts, whole grains and beans. Like manganese, molybdenum helps activate some enzymes and enables normal cell function. Dietary sources of molybdenum include milk, legumes, whole-grain breads and nuts.

Nutrients are elements or compounds that are vital for human growth, development and function. Macronutrients, which are protein, fat and carbohydrates, provide energy, but also have other roles. You need large amounts of these nutrients on a daily basis. Micronutrients, required in smaller amounts, are vitamins and minerals that are essential components of biological processes occurring throughout your body. Having a 
balanced diet and eating a variety of foods from all food groups ensures that you get all of the nutrients you need each day.

Iodine $(0.000016 \%)$ is required for making of thyroid hormones, which regulate metabolic rate and other cellular functions. Iodine deficiency, which can lead to goiter and brain damage, is an important health problem throughout much of the world. Iodine is critical for formation of thyroid hormones T3, or triodothyronine, and $\mathrm{T} 4$, or thyroxine. Inadequate production of thyroid hormones can cause enlargement of the thyroid gland, also known as goiter, while its deficiency during pregnancy can cause irreversible brain damage in newborns. However, you can get sufficient amounts of iodine by consuming iodized salt, seafood, eggs and milk.

Selenium (0.000019\%) is essential for certain enzymes, including several anti-oxidants. Unlike animals, plants do not appear to require selenium for survival, but they do absorb it, so there are several cases of selenium poisoning from eating plants grown in selenium-rich soils.

Chromium (0.0000024\%) helps regulate sugar levels by interacting with insulin, but the exact mechanism is still not completely understood.

Manganese $(0.000017 \%)$ is essential for certain enzymes, in particular those that protect mitochondria - the place where usable energy is generated inside cells - from dangerous oxidants.

Molybdenum $(0.000013 \%)$ is essential to virtually all life forms. In humans, it is important for transforming sulfur into a usable form. In nitrogen-fixing bacteria, it is important for transforming nitrogen into a usable form.

Cobalt $(0.0000021 \%)$ is contained in vitamin B12, which is important in protein formation and DNA regulation.

\section{Human body and chemicals}

Most of the human body is made up of water, H2O, with cells consisting of $65-90 \%$ water by weight. Therefore, it isn't surprising that most of a human body's mass is oxygen. Carbon, thebasic unit for organic molecules, comes in second. 99\% of the mass of the human body is madeup of just six elements: oxygen, carbon, hydrogen, nitrogen, calcium, and phosphorus. You may also wish to view the element composition of an average human body by mass.
1. Oxygen $(65 \%)$
2. Carbon $(18 \%)$
3. Hydrogen $(10 \%)$
4. Nitrogen $(3 \%)$
5. Calcium $(1.5 \%)$
6. Phosphorus $(1.0 \%)$
7. Potassium $(0.35 \%)$
8. Sulfur $(0.25 \%)$
9. Sodium $(0.15 \%)$

10. Magnesium $(0.05 \%)$

11. Copper, Zinc, Selenium, Molybdenum, Fluorine, Chlorine, Iodine, Manganese, Cobalt, Iron $(0.70 \%)$

12. Lithium, Strontium, Aluminium, Silicon, Lead, Vanadium, Arsenic, Bromine (trace amounts)

Elements And Diseases\& Food Source

\begin{tabular}{|l|l|l|l|}
\hline Element & Usual Food Source & Function, if any & $\begin{array}{l}\text { Hazard Caused by Excess in } \\
\text { Food (if known) }\end{array}$ \\
\hline Aluminium & $\begin{array}{l}\text { From cooking vessels, aluminium-containing } \\
\text { medications, some fruits and vegetables }\end{array}$ & $\begin{array}{l}\text { Poorly absorbed; no } \\
\text { known function }\end{array}$ & $\begin{array}{l}\text { Decreased phosphate absorption } \\
\text { leading to bone diseases, altered } \\
\text { mental function }\end{array}$ \\
\hline Antimony & Foods stored in enamel vessels and cans & No known function & Very low toxicity \\
\hline Arsenic & $\begin{array}{l}\text { Crustaceans and fish, contaminated water, fruits } \\
\text { and vegetables grown in contaminated areas or } \\
\text { with spray residues }\end{array}$ & $\begin{array}{l}\text { Possibly essential for } \\
\text { growth in rodents, pigs } \\
\text { and poultry }\end{array}$ & $\begin{array}{l}\text { Gut, skin, brain and nerves } \\
\text { affected }\end{array}$ \\
\hline Barium & Brazil nuts, cereals grown in barium- rich soil & $\begin{array}{l}\text { No known function; used } \\
\text { for X-ray studies }\end{array}$ & Very low toxicity \\
\hline Boron & Plant foods & $\begin{array}{l}\text { Not essential for animals, } \\
\text { although it is for some }\end{array}$ & Very low toxicity \\
\hline
\end{tabular}


Analysis Of Elements And Foods For The Human Body And Avoiding The Unnecessary

\begin{tabular}{|c|c|c|c|}
\hline & & plants & \\
\hline Bromine & From fumigated grain and its products & $\begin{array}{l}\text { Will replace chloride and } \\
\text { so accumulate; will also } \\
\text { be taken up by the } \\
\text { thyroid gland instead of } \\
\text { iodine }\end{array}$ & $\begin{array}{l}\text { Adverse effects on brain and } \\
\text { thyroid function }\end{array}$ \\
\hline Gold & Information inadequate & $\begin{array}{l}\text { No known function; gold } \\
\text { injections are used in the } \\
\text { treatment of rheumatoid } \\
\text { arthritis. }\end{array}$ & Skin, gut and kidney damage \\
\hline Lead & $\begin{array}{l}\text { Variable content in food; more in produce grown } \\
\text { near highways with vehicles using leaded petrol; } \\
\text { more in food from metal cans than from glass or } \\
\text { aluminium containers; some from reticulated water }\end{array}$ & Not essential & $\begin{array}{l}\text { World Health Organisation } \\
\text { suggests tolerable weekly intake } \\
\text { of } 50 \text { micrograms per kilogram } \\
\text { body weight for adults. Excess } \\
\text { affects brain, blood, bone and } \\
\text { kidneys. }\end{array}$ \\
\hline Rubidium & Soya beans, beef & $\begin{array}{l}\text { Can act partly as a } \\
\text { substitute for potassium }\end{array}$ & $\begin{array}{l}\text { More toxic an low potassium } \\
\text { diets, with effects on growth and } \\
\text { reproduction }\end{array}$ \\
\hline Silver & $\begin{array}{l}\text { From food prepared in silver-plated vessels, } \\
\text { contaminated by silver-lead solders or stored in } \\
\text { silver foil }\end{array}$ & Not essential & Low toxicity \\
\hline Strontium & $\begin{array}{r}\text { Plant foods have more than animal foods, unless } \\
\text { bone is a part. More in bran than the remainder of } \\
\text { cereal grain. }\end{array}$ & $\begin{array}{r}\text { Found in bone, and can } \\
\text { be replaced by } \\
\text { radioactive strontium } \\
\text { from fall-out; interacts } \\
\text { with calcium }\end{array}$ & May affect growth \\
\hline
\end{tabular}

\section{Other Elements}

Trace elements include iron, fluorine, zinc, silicon, rubidium, strontium, bromine, lead, copper and many more. Some trace elements are essential or have a beneficial effect on the body, while others have no known function or appear to be toxic. Some of the more prominent representatives are called macro nutrients, whereas those appearing only at the level of parts per million or less are referred to as micronutrients. These nutrients perform various functions, including the building of bones and cell structures, regulating the body's $\mathrm{pH}$, carrying charge, and driving chemical reactions. The FDA has set a reference daily intake for 12 minerals (calcium, iron, phosphorous, iodine, magnesium, zinc, selenium, copper, manganese, chromium, molybdenum and chloride). Sodium and potassium also have recommended levels, but they are treated separately. However, this does not exhaust the list of elements that you need. Sulfur is not usually mentioned as a dietary supplement because the body gets plenty of it in proteins. And there are several other elements - such as silicon, boron, nickel, vanadium and lead — that may play a biological role but are not classified as essential.

\section{Energy}

As carbohydrates break down during digestion, they are turned into glucose. Cells pick up glucose molecules with the help of insulin and use them for energy. When carbs are not around, your system automatically turns to fat or protein for energy, so it is important to have the right balance of each nutrient. Both carbohydrates and protein have 4 calories per gram, but fat is a concentrated source of energy offering 9 calories per gram. You need 45 to 65 percent calories from carbohydrates, which amounts to 225 to 325 grams for a 2,000-calorie diet, according to the Dietary Guidelines for Americans 2010. Between 10 and 35 percent of your calories need to come from protein, or 50 to 175 grams based on a 2,000-calorie diet. Fat should account for 20 to 35 percent of your calories. For a 2,000-calorie diet, this amounts to 44 to 77 grams of fat.

Some nutrients are vital to tissue growth and repair. Vitamin $\mathrm{C}$ builds collagen, a type of protein that is a structural component of cells, particularly skin cells. When you have an injury, collagen aids in the healing process of skin tissue. B vitamins, including pyridoxine, biotin and niacin, deconstruct complex protein compounds into simpler forms called amino acids. These smaller amino acid molecules stack on top of one another to create tissues, including muscle tissue. Iron is not involved in creating tissues, but it does carry oxygen around to cells and tissues so that they can continue to grow and function.

\section{Skeletal Strength}

Several nutrients work together to keep your bones and teeth strong. Calcium is the most abundant mineral in your body and it is the primary component of your skeleton. You also need vitamin D from your diet 
so calcium can be properly absorbed. Additionally, calcium works alongside phosphorous to create bone structure. Copper is a mineral you need in very small amounts each day, but if you don't get adequate amounts of copper, you may lose bone mass and increase your risk of osteoporosis.

\section{Digestion}

You need an array of different nutrients to digest food. Zinc is a mineral that is a structural part of more than 200 digestive enzymes, reports Lewis County, New York. These enzymes break food apart in your stomach and allow your small intestine to absorb vitamins and minerals. Riboflavin, pantothenic acid and other B vitamins work together to pull energy from the foods you eat. They aid in metabolizing carbohydrates into glucose and can get fuel from fat and protein if needed. Fiber, which is a type of complex carbohydrate, does not break down into glucose. Instead, fiber travels through your gut intact, keeping your bowels moving and pushing out waste.

Like iron and copper, zinc is an essential trace mineral, meaning your body only needs a small amount to stay healthy. Despite its relatively low intake requirements, however, every cell relies on the presence of zinc to function properly. The enzymes involved in immunity, wound healing, cell division and more than 100 other processes depend on zinc. Zinc also gives structure to cells and proteins. Although eggs contain some zinc, they're not a good source of the nutrient.

\section{Recommended Intake}

It's necessary to maintain a regular zinc intake to prevent deficiency, partly because your body doesn't have a dedicated storage system for the mineral. The Food and Nutrition Board at the Institute of Medicine sets the recommended dietary allowance, or RDA, guidelines for zinc, which vary by age and gender. The RDA for zinc for healthy men of all ages is 11 milligrams per day, while healthy women of all ages need 8 milligrams a day. Because zinc is essential for proper growth and development, pregnant women require 11 milligrams of zinc each day.

\section{Zinc in Eggs}

Much of an egg's vitamin and mineral content, including most of its zinc, resides in its yolk. The exact amount of zinc in a particular egg, however, depends on its size and what the producing chicken was fed. According to the U.S. Department of Agriculture, a raw jumbo-sized egg contains upwards of 0.81 milligrams of zinc, while a large, hard-boiled egg has just 0.52 milligrams of zinc. Men and pregnant women would have to eat about 21 large hard-boiled eggs a day -- or more than 1,600 calories worth of eggs -- to meet the RDA for zinc. Non-pregnant women would have to consume about 15 large hard-boiled eggs, or nearly 1,200 calories worth of eggs.

\section{Considerations}

Nearly all dietary guidelines recommend meeting daily energy requirements with a variety of nutrientdense foods. Getting most of your calories from just one type of food significantly increases the likelihood of vitamin and mineral deficiencies. Eggs, for example, don't supply any vitamin $\mathrm{C}$ or dietary fiber. Eggs are a significant source of dietary cholesterol, however, providing about 185 milligrams of cholesterol per large egg. Previous guidelines suggested that healthy individuals should limit their egg consumption to no more than three per week. Research indicates, however, that saturated fat affects blood cholesterol levels to a greater extent than dietary cholesterol. The American Heart Association therefore recommends that healthy people keep their egg intake to no more than one per day, and their total daily intake of dietary cholesterol below 300 milligrams. Individuals with high cholesterol levels should limit their egg consumption to no more than one per week.

\section{Other Sources}

Oysters are by far the best source of zinc -- a 3-ounce serving supplies 74 milligrams, according to USDA data. Beef, seafood, pork and dark-meat poultry are also high in zinc, as are dairy products such as yogurt, cheese and milk. Many foods of plant origin also contain significant amounts of zinc, including dried beans and peas, lentils, nuts and whole grains. Some box cereals are also fortified with the mineral. Your body absorbs zinc from animal products more readily, largely because these foods also contain amino acids that promote zinc absorption. Phytic acid, a natural compound found in whole grains, legumes and nuts, binds to zinc and reduces its rate of absorption. For this reason, vegans are more likely to be deficient in zinc than vegetarians who also consume some dairy products. our body makes many of the nutrients, known as nonessential, that it needs to carry out its functions. Some nutrients, however, can't be made rapidly enough -- or at all -- to meet daily needs; these are called essential nutrients. They must be obtained from outside sources, such as food or supplements. Your body depends on six groups of essential nutrients, and each is vital for growth, development and continuing health. 


\section{Vitamins}

Vitamins are organic -- derived from living matter -- compounds your body needs in small amounts to function properly. Because your body can't make these nutrients, you must get them from food or supplements. Vitamins play an important role in digestion, and they're crucial for body function regulation. Vitamins exist in two forms -- fat soluble, which include vitamins A, D, E and K, and water soluble, which include the B-complex vitamins and vitamin $\mathrm{C}$. To consume a wide variety of vitamins, include fresh fruits and vegetables, whole grains, low-fat milk, fish and eggs in your daily food plan.

\section{Minerals}

Minerals are inorganic compounds that your body is unable to manufacture. They help regulate body processes, and each one plays a particular role in your body's proper functioning. Your diet must provide 16 minerals to maintain optimum health. They come in two categories: Macro minerals -- sodium, potassium, chloride, calcium, phosphorus, magnesium and sulfur -- are needed in larger quantities by your body, while trace minerals -- iron zinc, iodide, selenium, copper, fluoride, chromium, molybdenum and manganese -- are required in smaller amounts. Include mineral-rich foods like fruits, vegetables, whole-grains, nuts and fortified low-fat milk in your diet.

\section{Protein}

Protein is a component of every cell, and your body uses it to build and repair tissues. Protein is made from amino acids, but your body is unable to produce all of them. Dietary protein, therefore, becomes the main source of these essential amino acids. Fish, lean meat, poultry, eggs and cheese are complete proteins, meaning they contain all the necessary amino acids. Incomplete proteins, such as grains, legumes, nuts and seeds, should be eaten in a wide variety to ensure you consume all necessary amino acids.

Fats

Your body requires monounsaturated and polyunsaturated fats, including omega-3 fatty acids, to maintain optimal health. Monounsaturated and polyunsaturated fats improve blood cholesterol levels, reduce inflammation and stabilize heart rhythms, says Harvard School of Public Health. Specifically, omega-3s are necessary for proper blood clotting and development of your brain's cell membranes. These fatty acids also help protect against heart disease, cancer and stroke. Include foods that contain good fats, such as salmon, tuna, olive oil, canola oil, flaxseed, walnuts and almonds in your daily food plan.

\section{Carbohydrates}

Your body doesn't manufacture carbohydrates, but they are broken down during digestion to provide fuel for physical activities and energy for proper body functions. Your nerves, muscles and brain depend on the energy provided by carbohydrates. According to Harvard School of Public Health, processing whole grains into refined foods, including white bread, sweets and white rice, removes minerals, fatty acids, as well as fiber, which results in foods that produce higher spikes in blood sugar than whole grains. Choose complex carbohydrates such as whole-grain breads, pasta and cereals, nuts, beans, lentils, peas and potatoes.

\section{Water}

Water makes up more than 60 percent of your body weight, according to MayoClinic.com. Your body's daily fluid requirement exceeds what your body can make through processes such as digestion. Because you must supply your body with enough water to keep it functioning properly, it's considered an essential nutrient. Water carries other nutrients and oxygen to cells, transports wastes away from cells, regulates body temperature and helps keep muscles and skin toned. Although individual water requirements vary. Your body needs inorganic compounds, often referred to as elements but more commonly known as minerals, to support growth, development and daily function. Although your body only needs small amounts of the mineral selenium, it plays an essential role in the production of proteins needed to keep the thyroid gland and immune system functioning properly. Consuming too much selenium can lead to selenium toxicity, a condition called selenosis.

\section{Recommended Intake}

The Institute of Medicine sets the recommended dietary allowance of selenium at 55 micrograms per day. This number represents the average daily dietary intake level sufficient to meet the needs of 97 to 98 percent of healthy adolescent and adult males and females. Failing to consume this amount of selenium over a period of time can lead to a deficiency that increases your risk for heart disease, hypothyroidism and a weakened immune system. Consuming higher amounts of selenium over a long period of time triggers the symptoms of selenosis. 


\section{Sources}

Many types of foods contain selenium, but the amount in any particular food depends upon the level of selenium in the soil where the plant was grown or the animal was raised. Brazil nuts contain the highest concentration of selenium, providing as much as 544 micrograms in an ounce of nuts. Meat and seafood, including tuna, cod, turkey, chicken and beef, also contain selenium. Foods made from grains, like oatmeal, bread, pasta and rice, contribute selenium to your daily diet. The soil in Nebraska and the Dakotas contains a high level of selenium, so foods grown and raised in these regions contain more selenium than in other parts of the country.

\section{Selenosis}

The Office of Dietary Supplements reports that high levels of selenium in your blood, defined as a concentration of more than 100 micrograms per deciliter, causes selenosis. The symptoms of selenosis include fingernail loss, skin rash, hair loss, weight loss, fatigue and irritability. You may also notice a garlic odour in your breath. Over time selenosis can cause mild nerve damage.

\section{Tolerable Upper Intake}

To avoid the dangers of too much selenium in your blood, the Institute of Medicine sets the tolerable upper intake level at 400 micrograms per day for anyone age 14 and older. In the United States, selenium toxicity is rare. However, those taking dietary supplements should take care to consume less than the recommended tolerable upper intake level. Also, because Brazil nuts can contain such high concentrations of selenium, consume these in moderation to avoid too $\mathrm{m}$ Grapes are a source of the minerals copper, potassium, manganese and iron. Grapes also contain calcium, phosphorus, magnesium and zinc, but only in trace amounts. The most commonly consumed grape in the United States is the Thompson Seedless grape, a green variety that is dried to produce raisins and is available fresh from summer to early winter. Be sure to incorporate differently coloured varieties of grapes into your diet as well, such as blueblack Fantasy grapes or red Ruby grapes. The amounts and types of minerals in all varieties are similar. A regular intake of the minerals in grapes may help decrease your risk of a variety of medical conditions.

\section{Copper}

A 1-cup serving of fresh red or green grapes contains 0.192 milligrams, or 10 percent of the amount of copper that the U.S. Department of Agriculture recommends daily for healthy adult men and women. The body needs only small amounts of copper, but the mineral is crucial for energy metabolism, iron absorption, nervous system health and red blood cell synthesis. If your diet lacks adequate copper, you may be more likely to develop anemia or osteoporosis. Pregnant and nursing women in particular need to be careful to consume plenty of copper-rich foods like grapes. They require between 100 and 400 micrograms more copper each day than women who are not pregnant or nursing.

\section{Potassium}

Adult men and women need approximately 4,700 milligrams of potassium each day, and eating 1 cup of fresh grapes can supply 6 percent of this requirement. Potassium is an electrolyte as well as a mineral. It contributes to the growth, repair and maintenance of bones and, along with sodium, keeps the electrochemical charges in cellular tissue balanced to allow muscle contraction and electrical impulse transmission. Consuming enough potassium may help prevent stroke, kidney stones, high blood pressure and osteoporosis. If you are concerned about your potassium levels, talk to your doctor about ways to lower your sodium intake. People who eat high-sodium foods may be more likely to become deficient in potassium.

\section{Manganese}

Every 1-cup serving of red or green grapes provides 6 percent of the RDA of manganese for women and 4.6 percent of the RDA for men. Like copper, the body only requires trace amounts of manganese, though the University of Maryland Medical Center reports that up to 37 percent of Americans may not consume enough of the mineral regularly. Manganese aids in bone development, hormone synthesis and calcium regulation. It supports the function of the nervous system and is part of the structure of the superoxide dismutase enzyme, a powerful antioxidant. A diet that lacks manganese-rich foods may increase your risk of infertility, arthritis, epilepsy and osteoporosis. Women deficient in manganese may experience an increase in premenstrual syndrome symptoms.

\section{Iron}

Grapes supply 0.54 milligrams of iron per cup. This amount is 6.7 percent of a man's daily iron requirement and 3 percent of a woman's requirement. The body uses iron to synthesize red blood cells and 
adenosine triphosphate, or ATP. ATP is the molecule that cells use as their main energy source. People who don't consume enough iron may be more likely to develop anemia or neurological problems like attention-deficit hyperactivity disorder. The iron in plant foods like grapes is non-heme iron. This form of iron is not as easily absorbed as the heme iron found in poultry, meat and fish. You can increase the amount of iron you receive from grapes by eating them with a rich source of vitamin $\mathrm{C}$ or with meat. Try serving grapes on a fruit plate along with melons, strawberries and orange segments. Or mix sliced grapes into your favorite chicken salad recipe.

\section{Conclusion}

This food advisor will be helpful to the human being by monitoring the level or their perfect percentage in the human body daily and advise the human being to take the necessary food in the correct ratio daily or at regular interval. It can be applicable to even such animals like cow, goat to cure their diseases. The animals will take the necessary food by continuous monitoring of this elements in the body. This kind of research can be extended to identify the human being or animal in the future.

These chemicals or compound can be checked periodically and can identify the people using this data. Research can be made in this wide area and can conclude that no research is made on this concept so in future it will be very useful to the people.if they take food according to the food advisor there is no chance for death and man can live happily forever.

\section{Reference}

[1]. A review on role of essential trace elements in health and disease Lingamaneni Prashanth ${ }^{1}$, Kiran Kumar Kattapagari ${ }^{2}$, Ravi Teja Chitturi $^{2}$, VenkatRamana Reddy Baddam ${ }^{2}$, Lingamaneni Krishna Prasad ${ }^{3}$ 